\title{
GREEK AND LATIN IN SYRIAC SCRIPT
}

\author{
SEBASTIAN P. BROCK \\ UNIVERSITY OF OXFORD
}

\begin{abstract}
This article surveys the manuscript evidence for instances of Greek and Latin Garshuni texts. This evidence includes Greek and Latin texts written in either the Syriac script or Christian Palestinian Aramaic script, and one example of a Syriac text written in Greek script.
\end{abstract}

Syriac manuscripts containing extended passages of Greek in Syriac script are rare, and this is even more so the case with Latin. In the present contribution attention is primarily focused on three examples of Greek in Syriac script, and one each of Greek in Christian Palestinian Aramaic script, and of Latin in Syriac script. At the end, by way of contrast, a striking modern example of the reverse, Syriac in Greek script, is briefly introduced.

\section{A. GREEK IN SYRIAC SCRIPT}

A passage in Oswald Parry's Six Months in a Syrian Monastery, published in 1895, mentions a remarkable example to be found in a Gospel manuscript which alas appears not to have survived the twentieth century. After listing the manuscripts he had seen in Dayro d-Kurkmo (Deyrulzafaran), Parry stated that Midyat was the 
only other place with a library that he was able to see, and he comments: ${ }^{1}$

The most interesting book at Midhiat is a small copy of the Gospels in most exquisite Estrangeli characters, but in the Greek language, which is valuable as showing that the present custom of writing the current language in Syriac character is an old one. The book belongs to the ninth century, and is written on fine vellum; it contains many words, on whose transliteration the writer was doubtful, in Greek letters on the margin, and would form a valuable guide to the pronunciation of Greek at that date.

One wonders what was the fate of this precious document.

Curiously enough it was also from Midyat that another manuscript comes, containing, this time, only a limited amount of Greek in Syriac script. The manuscript, said to be of the eighth or ninth century, but probably representing the usage of the sixth or seventh century, was published by Rahmani in the third volume of his Studia Syriaca, on the basis of a modern copy (Charfet, Fonds patriarcal 87). ${ }^{2}$ The text in question is the Rite for the reception of a bishop; while the main text is in Syriac, the parts contributed by the Archdeacon and Deacon are in Greek, but written in Syriac characters. The length of the passages in Greek, however, is always very short, the longest being only of five or so words at a time. A few other manuscripts of this sort can be found, notably Vatican Borgia Syriac 13, of the twelfth century, and in some of the liturgical scrolls among the 'New Finds' from St Catherine's Monastery, Sinai. ${ }^{3}$

${ }^{1}$ O. Parry, Six Months in a Syrian Monastery (London, 1895), p.338.

2 I.E. Rahmani, Studia Syriaca III. Vetusta Documenta Liturgica III (Charfet, 1908), pp.1-4. The document is of considerable liturgical interest; for this aspect, see especially G. Khouri-Sarkis, 'Réception d'un évêque syrien au sixième siècle', L'Orient Syrien 2 (1957), pp.137-84, R.F. Taft, The Great Entrance (OCA 200; 1975), pp.40-42, and 'Worship on Sinai in the first Christian millennium', in E.J. Gerstel and R.S. Nelson (eds), Approaching the Holy Mountain. Art and Liturgy at St Catherine's Monastery in the Sinai (Turnhout, 2010), 156-61.

${ }^{3} \mathrm{E} 1 \mathrm{~N}, \mathrm{E} 3 \mathrm{~N}, \mathrm{E} 19 \mathrm{~N}$. Contrast E22N where both Greek and Syriac scripts are employed. Bilingual manuscripts, with Greek and Syriac translation juxtaposed, seem to be extremely rare; X239N, among the Greek 'New Finds', would seem to be an example. 
The three examples of manuscripts containing Greek in Syriac script which are briefly described below are all liturgical and of Syrian Orthodox or Melkite provenance; each has a slightly different way of representing the Greek vowels, and it is in this respect that they are likely to be of some interest for the developments in the pronunciation of particular Greek vowels, since the manuscripts belong to a period, $c a$. ninth to eleventh centuries, for which there is not very much good evidence.

(1) The first example is a fragment of the Anaphora of St James in the National Museum in Damascus. ${ }^{4}$ The text, consisting of two bifolia, has been published, with photographs, by Sauget ${ }^{5}$ who dated the script (Estrangelo with occasional Serto features) to between the ninth and the eleventh centuries. The first surviving folio opens in the middle of the pre-Sanctus prayer; this, as well as the post-Sanctus prayer, is in Syriac, but at the point where the priest introduces the Sanctus, raising his voice, the language turns to Greek, and it is Greek that the reply of the people is given. From the words of Institution onwards (the text reaches up to the Fraction $^{6}$ and Consignation) all is in Greek, apart from the rubrics which throughout are in Syriac.

The treatment of Greek consonants follows the standard practice found in the vast majority of Greek loanwords in Syriac, ${ }^{7}$ where Greek theta is represented by Syriac tau, and Greek taw by Syriac teth, and Greek kappa is represented by Syriac qoph and Greek chei by Syriac kaph. The doubling of Greek letters is ignored.

${ }^{4}$ At least until the present crisis it was on view in one of the public galleries.

5 J.-M. Sauget, 'Vestiges d'une célébration Gréco-Syriaque de l'Anaphore de Saint Jacques', in C. Laga, J.A. Munitiz, L. van Rompay (eds), After Chalcedon. Studies in Theology and Church History offered to A. van Roey (OLA 18 (1985), pp.309-45; he discusses the transliteration of the Greek on pp.310-14. Cf. also S.P. Brock, in Ph. Christides (ed.), A History of Ancient Greek (Cambridge, 2007), p.825.

${ }^{6}$ The wording includes the phrase 'we break the heavenly bread', which was the source of much controversy in Syrian Orthodox circles in the late eighth and early ninth century, a point discussed by Sauget, 'Vestiges', pp.335-45.

${ }^{7}$ For a detailed study see A.M. Butts, Language Change in the Wake of Empire: Syriac in its Greco-Roman Context (Dissertation, Chicago, 2013), pp.88-128 (and pp.128-181 for vowels). 
For vowels the practice, which is reasonably consistent, is as follows:

Alaph: a distinction is made between alaph with a point above $(\dot{\kappa})$, which represents Greek alpha, and alaph with a point below ( $(r)$, which represents Greek epsilon and the diphthong alpha + iota $(\varepsilon, \alpha l)$, these two being already pronounced in the same way.

Waw: without any points can represent, not only both Greek omikron and omega $(0, \omega)$, but also upsilon (U) and the diphthong epsilon + upsilon (घU). Waw with a point above (a) once represents omega, while waw with two points below (a) regularly represents the diphthong omikron + upsilon (ov).

Yodh represents eta, iota and the diphthong epsilon + iota ( $\eta$, l, $\varepsilon \iota)$, all of which would have been pronounced [i].

Combinations of two Syriac letters are also found; thus:

Alaph + waw (or) are used for the following:

(1) occasionally this combination represents Greek omega $(\omega) ; 8$

(2) it may represent the diphthong alpha + upsilon (av);

(3) it may represent the diphthong epsilon + upsilon (Eu).

Alaph + yodh $(, \approx)$ represents initial eta and initial epsilon + iota $(\eta, \varepsilon l)$.

Yodh + waw with two points above (ä) represents Greek vowels upsilon and the diphthong omikron + iota $(u, o l)$; examples in lines 1, 9, 11 and 17 of Sample I. Both of these Greek were probably still pronounced [ü], and had not yet merged with [i].

The Greek rough breathing is represented for viós but not for i $\mu \varepsilon \tilde{c} s$ etc.; there is one example of a pseudo-correction,

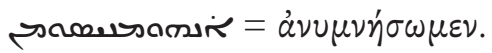

${ }^{8}$ Compare the similar use of Armenian $a y b+$ biwn (uu) to represent omega. 


\section{Sample I}

\section{Damascus Fragment:}

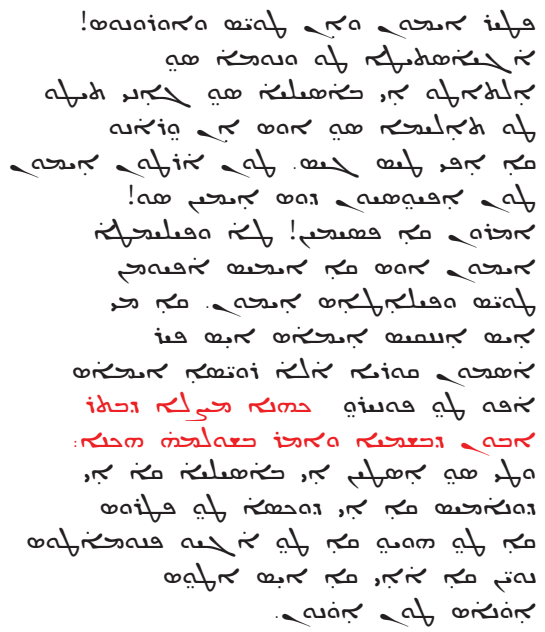

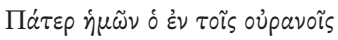

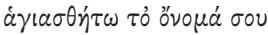

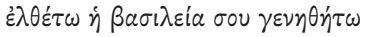

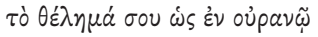

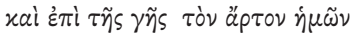

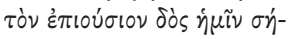

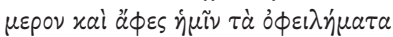

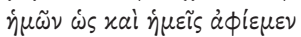

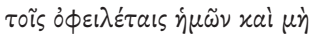

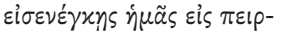

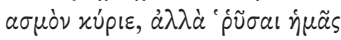

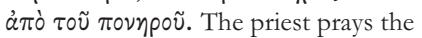
prayer after the Our Father in heaven, thus

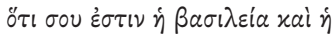

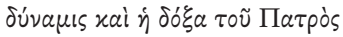

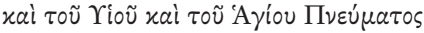

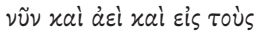

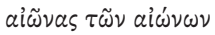

In tabular form we have for the Greek vowels (for the consonants, see Table III):

\section{Table I}

\begin{tabular}{|c|c|}
\hline$\alpha$ & $\dot{\sim}$ \\
\hline$\alpha l$ & $\widetilde{r}$ \\
\hline$\alpha u$ & ar \\
\hline$\varepsilon$ & $\kappa$ \\
\hline$\varepsilon l$ & , \\
\hline દU & ar \\
\hline 0 & $a$ \\
\hline Ol & هة \\
\hline ov & o \\
\hline$u$ & هي \\
\hline$\omega$ & \\
\hline
\end{tabular}

(2) The second example is provided by Sinai Syr. 27, to which Mingana Syr. 659 and British Library Or. 8610.II and Hiersemann 
500/48 belong; 9 the contents are Troparia, and the date is perhaps eleventh century.

The consonants follow the same pattern as in the Damascus fragment, with three exceptions: (1) the doubling of Greek consonants is represented; (2) psei may also be represented by beth + semkath; and (3) Greek chi is represented by Syriac shin when it precedes the front vowels [e] or [i]. This latter feature (e.g. Sample II, line 1) is also found in the representation of Greek loanwords in

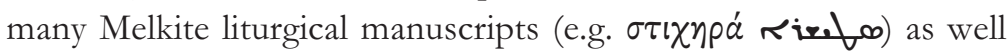
as in several Greek dialects.

For the representation of Greek vowels there are several differences and some refinements:

Alaph: again there is the differentiation between Greek alpha and epsilon/alpha + iota $(\alpha, \varepsilon / \alpha \mathrm{l})$, the latter being designated by alaph with the vowel sign rboso placed beneath it $(\widetilde{x})$.

Waw denotes both omikron and omega (both would have been pronounced the same), ${ }^{10}$ though on occasion omega is represented by waw with a small supralinear omega. Waw with a line under it ( $\subseteq$ ) represents the Greek diphthong omikron + iota (Oı); examples are in lines 7 and 9 of Sample II. Waw with < placed beneath it represents both upsilon and the diphthong omikeron + upsilon $(\mathrm{U}, \mathrm{OU})$; examples are in lines 1, 3, 5 and 6 of Sample II.

Yodh represents eta, iota and epsilon + iota $(\eta, l, \varepsilon l)$, as in the Damascus fragment.

The following combinations are found:

Alaph + waw (or) represent the diphthongs alpha + upsilon (av) and epsilon + upsilon (Ev), though for the latter alaph + yodh + waw $(\sim \kappa)$ is sometimes found.

${ }^{9}$ See P. Géhin, 'Manuscrits sinaïtiques dispersés III: les fragments syriaques de Londres et de Birmingham', Oriens Christianus 94 (2010), pp.33-4, 49. A more detailed study of the representation of Greek in Syriac script in this manuscript, by P. Géhin, is to appear in J. den Heijer, A. Schmidt, and T. Pataridze (eds.), Scripts beyond Borders (Leuven, forthcoming).

10 Thus they are frequently confused in Greek manuscripts of this period. 
Alaph + yodh $(, \sim)$ represents initial eta and initial epsilon + iota $(\eta, \varepsilon l)$.

The Greek rough breathing is represented for Yioũ, but not for

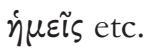

It will be noticed that waw with sublinear $<$ covers both upsilon and the diphthong omikron + upsilon (ou); thus, in contrast to the Damascus fragment, upsilon is differentiated from the diphthong omicron + iota (Ol).

Though the Greek rough breathing is not represented for the article, elsewhere it is occasionally denoted by $h e$.

\section{Sample II}

Sinai Syr 27 (from last folio of quire 15)

(a)

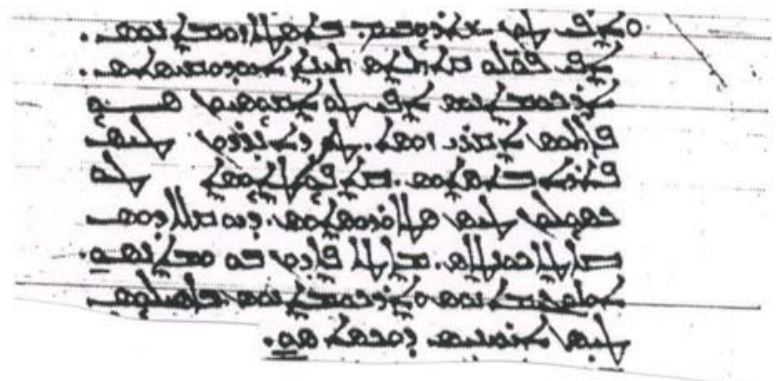

(b)

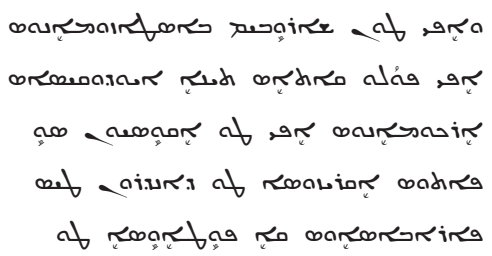

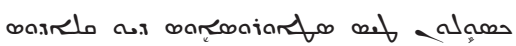

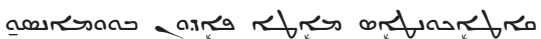

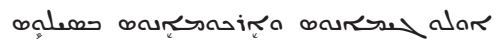
N

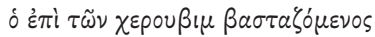

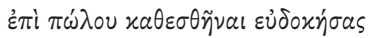

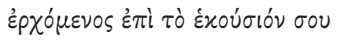

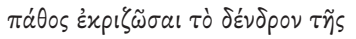

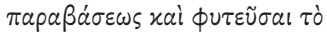

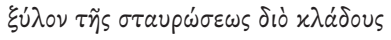

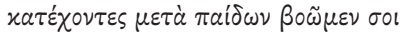

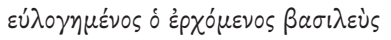


(3) Among the 'New Finds' at the Monastery of St Catherine, Sinai, are a number of liturgical scrolls which combine both Greek and Syriac languages; in some of these (notably E9N, E22N) the Greek is in Greek script, ${ }^{11}$ while in others short passages in Greek are given in Syriac script. ${ }^{12}$ More extended prayers in Greek but written in Syriac script are found in Sinai Syr. E18N. ${ }^{13}$

Unlike the Damascus fragment and Sinai Syr. 27, no diacritical signs are employed to differentiate between Greek vowels, and for the Greek consonants there are several distinctive representations, thus:

kappa is represented by kaph, and not qoph (thus, for example, xaí features as حص);

pei is sometimes represented by beth (see lines 1 and 4 of Sample III), presumably under the influence of Arabic.

sigma is represented by zayn when it precedes $m u$;

tau may be represented by (1) teth, as would be expected; or (2) by tau, or (3) by dalath when it follows $n u$ (see lines 1-2, 4 of Sample III), as in Modern Greek.

A further feature anticipating Modern Greek pronunciation is provided by the representation of epsilon + upsilon (عu) by alaph + pe ( $a$ ) , an example of which is to be found in lines 2-3 of Sample III.

The observations here on the usage in $\mathrm{E} 18 \mathrm{~N}$ are necessarily limited to a transcription of the short text that is available in the photograph in Mother Philothea's Catalogue. ${ }^{14}$

\section{Sample III}

\section{Sinai Syr E18N}

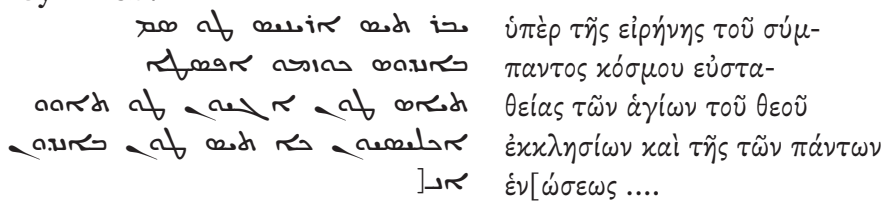

11 This also applies to the Melkite Vatican Syr. 41.

12 See note 3 , above.

${ }^{13}$ This also seems to be the case in E9N.

14 Philothée du Sinaï, Nouveaux manuscrits syriaques du Sinaï (Athens, 2008), p.64. 
In view of the brief character of the Sample of E18N that is all that is available, the limited evidence from this text is given in Table III, in combination with that from the Damascus fragment and Sinai Syr. 27, in order to bring out the distinctive characters of each. As will become clear from section B, below, some of the distinctive features of E18N, such as the representation of $\pi \tau$ and $a v / \varepsilon v$, will turn up again in Section B, with Christian Palestinian Aramaic.

\section{Table III}

\begin{tabular}{|c|c|c|c|}
\hline & Damascus & Sinai 27 & Sinai E18N \\
\hline$\alpha$ & $\dot{r}$ & $\kappa$ & $r$ \\
\hline$\beta$ & 3 & 3 & \\
\hline$\gamma$ & $\lambda$ & $\lambda$ & \\
\hline$\delta$ & $x$ & $x$ & $x$ \\
\hline$\varepsilon$ & $?$ & $\widetilde{\alpha}$ & $\kappa$ \\
\hline$\zeta$ & 1 & 1 & \\
\hline$\eta$ & , א, & 。 & . \\
\hline$\theta$ & $d$ & d & 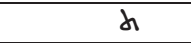 \\
\hline$\imath$ & , & , & 0 \\
\hline$x$ & م & م & $n$ \\
\hline$\lambda$ & $J$ & $J$ & $J$ \\
\hline$\mu$ & ד & ד & ד \\
\hline$\nu$ & $\Delta$ & $\Delta$ & 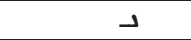 \\
\hline$\xi$ & ح & حه & ح \\
\hline$O$ & o & a & $a$ \\
\hline$\pi$ & 9 & 9 & $=9$ \\
\hline$\varrho$ & $i$ & $i$ & $i$ \\
\hline$\sigma$ & $\infty$ & $\infty$ & 10 \\
\hline$\tau$ & $t$ & $t$ & $t x$. \\
\hline$u$ & ja 0 & $0 ?$ &, 9 \\
\hline$\varphi$ & 9 & 9 & 9 \\
\hline$x$ & 4 & $\therefore 4$ & $=n$ \\
\hline$\psi$ & $\infty 9$ & $\infty$ & \\
\hline$\omega$ & $a$ ar & $0: 2$ & $a$ \\
\hline$\alpha_{l}$ & $?$ & $\kappa$ & $\kappa$ \\
\hline$\alpha u$ & ar & an & $9 \pi$ \\
\hline 80 & $a r$ & אֶם אח & תr \\
\hline$\varepsilon l$ & , א, & ת & $\infty$ \\
\hline $\mathrm{Ol}$ & ;a & $\cong$ & , \\
\hline OU & o & $?$ & a \\
\hline
\end{tabular}




\section{B. GREEK IN CHRistian PALESTINIAN ARAMAIC SCRIPT}

An important witness to the practice of writing Greek in a Semitic script is provided by British Library, Or. 4951, a collection of Melkite ordination services, ${ }^{15}$ making use of four different languages, Arabic (in Syriac script), Syriac, Christian Palestinian Aramaic, ${ }^{16}$ and Greek in Christian Palestinian Aramaic script. On ff. $43 \mathrm{v}-69 \mathrm{v}$ there is a second set of ordination services in a mixture of Christian Palestinian Aramaic and Greek in Christian Palestinian Aramaic script, an earlier set of ordination services having been provided in Syriac (ff.16r-26r). The text of ff.43v-69v has been edited by Black in his Rituale Melchitarum, ${ }^{17}$ but the passages of Greek in Christian Palestinian Aramaic have been represented in Greek script, and so the discussion here is based on a transcription of the text illustrated in his Plate II (f.55r). Black does, however, provide a helpful discussion of the system used for representing Greek in Christian Palestinian Aramaic script. ${ }^{18}$

As was the case with E18N, the representation of the Greek consonants has a number of distinctive features, thus:

delta: while normally dalath is used for delta, initial delta, especially when close to another delta, is represented by

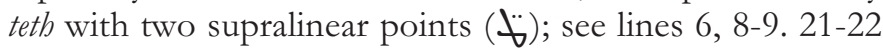
of Sample IV for examples.

theta is represented by tau with a supralinear point (di), thus distinguishing it from tau when it represents Greek tau (as it often does; see below). Line 2 provides an example.

kappa is normally represented by kaph, rather than qoph, thus following the practice found in $\mathrm{E} 18 \mathrm{~N}$; thus regularly for xaí, and further examples will be found in lines 2 and 5 of

${ }^{15} \mathrm{On}$ its liturgical significance, see H. Brakmann, 'Die altkirchlichen Ordinationsgebete Jerusalem', Jabrbuch für Antike und Christentum 47 (2004), 108-27.

${ }^{16}$ This is used for the 'Liturgy of the Nile' (ff.16v-42v), published by G. Margoliouth, 'The Liturgy of the Nile', Journal of the Royal Asiatic Society 1898, pp.677-731.

${ }_{17}$ M. Black, Rituale Melchitarum. A Christian Palestinian Euchologion (Stuttgart, 1938).

${ }^{18}$ Black, Rituale Melchitarum, pp.27-28. 
the Sample. Several cases, however, are to be found where qoph is used for kappa (e.g. in lines 7, 8-9, 12).

$x e i$ is represented by kaph + sadhe ( $\mathbf{s}$; rather than kaph + semkath, as is regularly found in Syriac); see line 7 of the Sample.

pei is represented either by beth (as lines 3, 23 of the Sample), or by reversed pe with two points above it (as line 22).

sigma, when intervocalic, is sometimes represented by sadhe, rather than the normal semkath; see lines 12, 21.

tau is represented by teth when it is followed by alpha $a^{19}$ or omega (see lines 6, 21), but by Syriac tau when other vowels follow.

chei is represented by kaph with two supralinear points (ت)), thus providing a distinction between it and kaph when it represents kappa (as is frequently the case). When chi is followed by the front vowels [e] and [i], it is represented by shin, as was the case in Sinai Syr. 27. An example will be found in line 16 of Sample IV.

The representation of Greek vowels likewise shows several distinctive features.

Alaph normally features with one of four different diacritical features; thus (1) alaph with two supralinear points ( $\ddot{\sim})$ represents alpha; (2) alaph with two sublinear points $(\boldsymbol{r})$ represents epsilon and alpha + epsilon $(\varepsilon, \alpha \mathbf{l})$; (3) alaph with a small supralinear omega may represent omega (see lines 6, 11 of Sample IV); and (4) alaph with a small supralinear omikron my represent omikron (see line 8 of the Sample).

Waw represents both omikron and omega, though the latter may also be represented by waw with a small supralinear omega (see line 15 of Sample IV); waw with a back slant above it may also represent both omikron and omega (thus both omikeron and omega may be represented in several different ways). Waw also represents omikron + upsilon (ou), as in

${ }^{19}$ Line 7 of Sample IV, however, provides an exception. 
lines 2-3. Occasionally ou is also represented as waw + he (๓о), though no example occurs in the Sample.

Yodh represents not only eta, iota and epsilon + iota ( $\eta, l, \varepsilon \iota)$, but also upsilon (see lines 6 and 10 of Sample IV) and the diphthong omikron + iota $(\mathrm{U}, \mathrm{O})$ ), indicating that the shift in the pronunciation of $v$ and $o r$ from [ü] to [i] had taken place.

The combination alaph + pe with two point above the pe (ق̋ ) represents both alpha + upsilon (av) and epsilon + upsilon (EU), thus again anticipating the Modern Greek pronunciation [ef]; examples will be found in lines 9, 21 and 21 of Sample IV.

The combination waw + he represents both ou and $\omega$.

Rough breathings are not represented, even with Yiou (thus f.51v man).

Finally, it will be seen that a prosthetic vowel (represented by alaph) is provided before initial consonantal clusters (e.g lines 5 and 17 of the Sample).

\section{Sample IV}

Christian Palestinian Aramaic: BL Or. 4951, f. 55b-56a

5

10

15

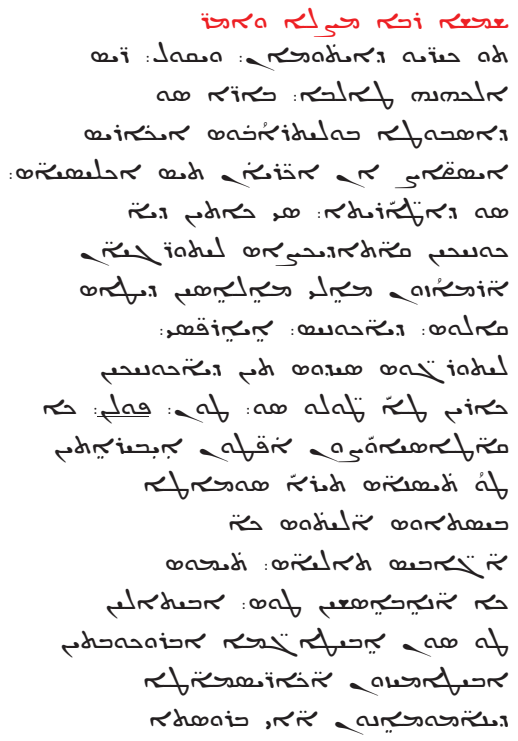

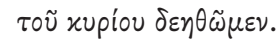
$\pi \alpha \rho \dot{\alpha} \sigma 0 \tilde{u}$

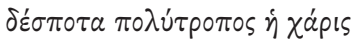

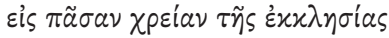

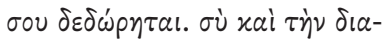

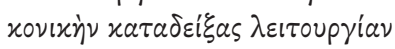
$\dot{\alpha} \rho \mu o^{\prime} \zeta \omega \nu \mu \varepsilon^{\prime} \lambda \eta \mu \varepsilon^{\prime} \lambda \varepsilon \sigma \nu \nu \delta ı \delta \alpha \sigma-$

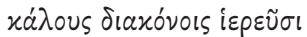
$\lambda \varepsilon i \tau o u p \gamma o u ́ s . \sigma \dot{~ \delta o ̀ s ~ \tau i ̀ v ~ \delta เ a x o v i x i ̀ v ~}$

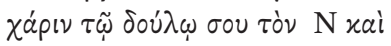

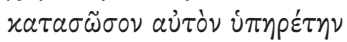

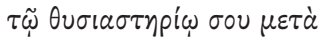
$\pi i \sigma \tau \varepsilon \omega \varsigma$ à $\lambda \eta \theta 0 \tilde{s} s$ xai

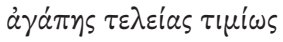

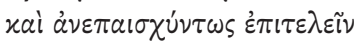
$\tau \dot{~ \sigma o ̀ \nu ~ \varepsilon ̇ \pi i ́ \tau \alpha \gamma \mu \alpha ~ \pi \rho o x o ́ ~ \pi \tau \varepsilon เ \nu ~}$

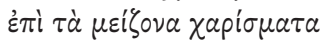

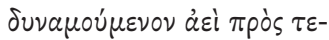




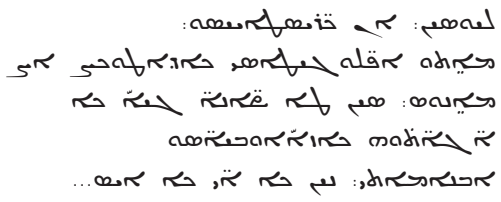

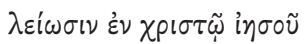

$\mu \varepsilon \theta^{\prime}$ oũ $\varepsilon \dot{\lambda} \lambda \circ \gamma \eta \tau \dot{s} \varsigma \sigma \dot{v}$ xaì $\delta \varepsilon \delta \circ \xi \dot{\xi} \sigma-$

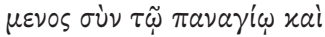

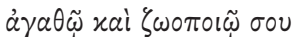

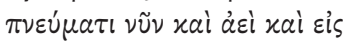

\section{Table IV}

\begin{tabular}{|c|c|c|c|}
\hline$\alpha$ & $\ddot{r} \sim \mathcal{R}$ & $\pi$ & $\ddot{e}=$ \\
\hline$\beta$ & 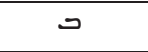 & $p$ & $\ddot{i}$ \\
\hline$\gamma$ & $\ddot{-} \gg$ & $\sigma$ & 50 \\
\hline$\delta$ & $b^{\prime \prime} \cdot$ & $\tau$ & $\rightarrow \dot{x} x$ \\
\hline$\varepsilon$ & $\ddot{\sim} \kappa$ & U & , \\
\hline$\zeta$ & 1 & $\chi$ & ב \\
\hline$\eta$ & , & $\psi$ & حص \\
\hline$\theta$ & di $x$ & $\omega$ & $\ddot{\sim} \sim$ ma ă a \\
\hline$l$ & ' & $\alpha l$ & $\kappa$ \\
\hline$x$ & حط م & $a v$ & كُم \\
\hline$\lambda$ & \rfloor & $\varepsilon l$ & , את \\
\hline$\mu$ & ד & $\varepsilon U$ & ق \\
\hline$v$ & r & Ol & ' \\
\hline$\xi$ & ح & ov & $a$ ma \\
\hline 0 & $r^{2} \circ a$ & & 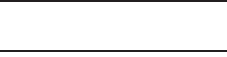 \\
\hline
\end{tabular}

\section{LATIN IN SYRIAC SCRIPT}

In 1549 the Syrian Orthodox priest Mushe of Mardin, ${ }^{20}$ then in Rome, copied out the Missale Romanum (and some other short liturgical texts) in Syriac script for the benefit of another oriental cleric then in Rome, the Ethiopian bishop Sahyun. ${ }^{21}$ This manu-

${ }^{20}$ Mushe subsequently worked with J.A. Widmanstetter on producing the first printed edition of the Syriac New Testament (published in Vienna in 1555).

${ }^{21}$ For the background, see J. Leroy, 'Une copie syriaque du Missale Romanum de Paul III et so arrière-plan historique', Mélanges de l'Université Saint-Joseph 46 (1970/1), p.353-82. 
script, now British Library, Harleian 5512, provides by far the most extensive example of Latin in Syriac script. ${ }^{22}$

Mushe had the advantage, not available to the men behind all the previous examples, of having available the Syriac vowel symbols for Latin a, e, i, o, and $u$, as well as the use of qushshaya/ rukkaka to distinguish the hard or soft pronunciation of beth, gamal, dalath, kaph, pe and tau.

Thus in the case of the consonants, beth with a supralinear point (qushshaya) represents Latin b, while beth with a sublinear point (rukkaka) represents Latin $\mathrm{v}$.

Similarly pe with a point above represents Latin p, while with a point below it represents Latin $\mathrm{f}$.

Kaph with a supralinear point (خ) represents both Latin c and q.

It is interesting to note that the Italian pronunciation of -ciand -ti- is witnessed, respectively, by the use of shin with three sublinear triangular points $(\mathbf{r})$ and taw + semkath (od).

\section{Sample V}

Latin: BL. Harl. 5512

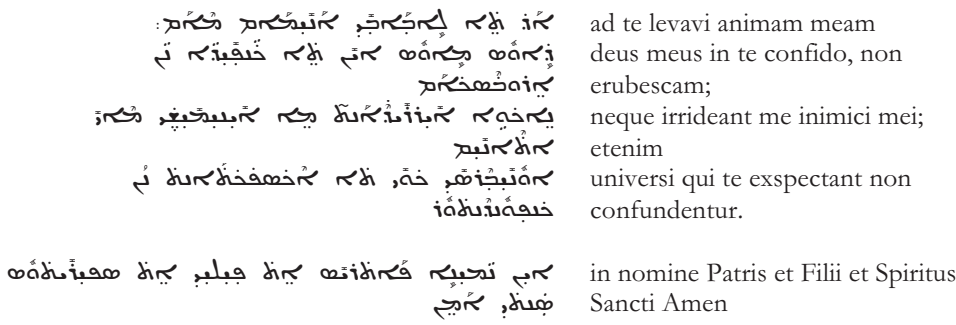

\section{Table V}

\begin{tabular}{|c|c|}
\hline ₹ & o \\
\hline$\dot{~}$ & $\mathrm{p}$ \\
\hline$\dot{n}$ ci $\stackrel{z}{*}$ & $q$ \\
\hline i & r \\
\hline$\kappa$ & $\mathrm{s}$ \\
\hline
\end{tabular}

$22 \mathrm{~W}$. Wright, Catalogue of the Syriac Manuscripts in the British Museum acquired since the year 1838 (London, 1870), pp.214-5. Other examples contain only short texts, such as the Ave Maria in the Maronite Vatican Syr. 477 (f.116v) of the sixteenth/seventeenth century. 


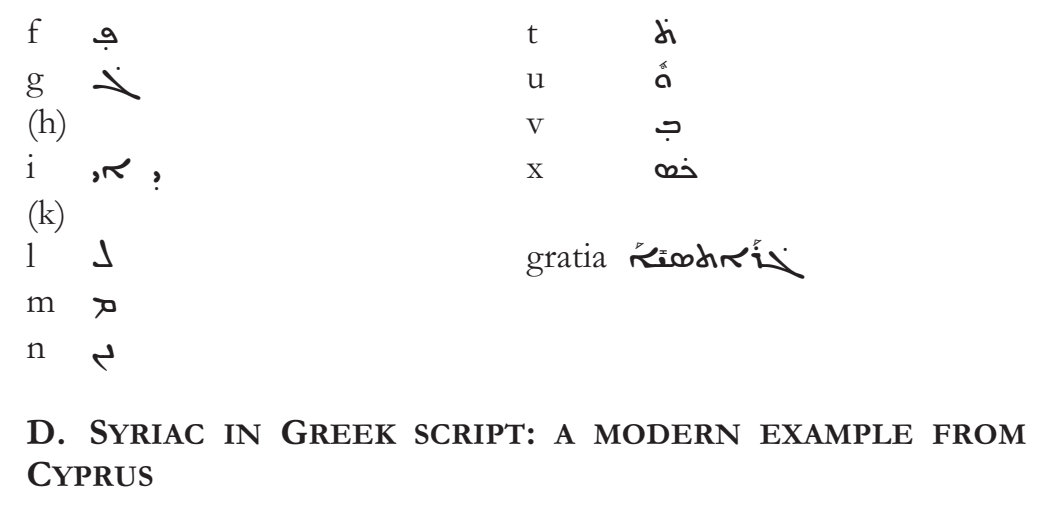

One place where the Greek and Syriac languages have met over at least the last half millennium is in the Maronite community in Cyprus. Among the earlier Maronite liturgical manuscripts from Cyprus, Vatican Syr. 477, of the sixteenth/seventeenth century, contains two passages (ff.5r-6r and 73r-74r) where, in the course of the marriage service, exhortations are given to the bridal couple in Greek, but written in Syriac script, thus conforming with the examples in Section A. This is not surprising, seeing that Maronite priests, probably coming from the mainland, would have been more familiar with Syriac than with Greek script. What is intriguing is that the reverse is the case in a modern liturgical printed book published for use in the Greek-speaking Maronite community in Cyprus, and edited by the noted liturgical scholar Mgr Butrus Gemayel when he was Archbishop of Cyprus (1988-2008). Running to 264 pages, the book contains the main liturgical services for the year, with texts in Greek, Syriac and Arabic, all in Syriac script. ${ }^{23}$

Unlike the case of Vatican Syr. 477, written for the use of the priest, the printed book is specifically intended for the use of Greek-speaking Maronite laity in Cyprus, and a Modern Greek translation is juxtaposed alongside the Syriac text in Greek characters, as in Sample VI below, with three stanzas of the wellknown hymn 'In your light we see the light', taken from p.6 of the edition.

${ }^{23}$ I am most grateful to the Revd Professor Joseph Moukarzel, of the Universite Saint-Esprit de Kaslik, for kindly sending me a pdf of the text. The date of publication appears to be 1993 . 
Since beta and delta cannot not serve in Modern Greek to represent beth and dalath, $\mu \pi$ and $\nu \tau$ are used for these. For characters not found in the Greek alphabet, underlining is employed: the he is represented by underlined $c h i$, and shin by underlined sigma.

\section{Sample VI}

\section{Syriac in Greek Characters}

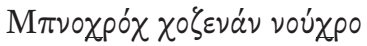

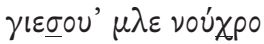

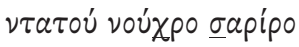

$\nu \tau \mu a v \chi a ́ \rho ~ \mu \pi \varepsilon p l o ́ \tau o$

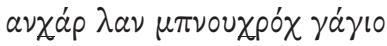

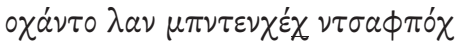

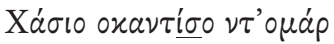

$\mu \pi \mu \varepsilon v \tau \gamma$ lopái voúxpo

$\chi \lambda l \mu \varepsilon \nu \alpha \dot{\nu} \chi \alpha \underline{\sigma} \varepsilon \mu \pi i \underline{\sigma} \varepsilon$

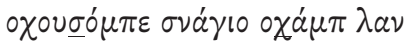

$\nu \tau \alpha \mu \pi \nu \tau \alpha \chi \gamma 10 \cup ́ \tau \lambda \varepsilon^{\prime} \mu \pi \circ$

$\nu \varepsilon^{\prime} \mu \pi \varepsilon \nu \tau \tau^{\prime} \mu \pi \circ \nu \tau \varepsilon \nu \tau \chi\left\llcorner\nu \circ v^{\prime} \tau\right.$.

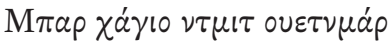

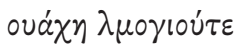

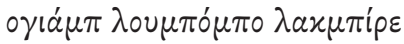

o $\sigma \dot{\alpha} \mu \pi \rho \circ \lambda \alpha \sigma \chi \chi \mu \pi \varepsilon$

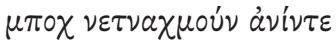

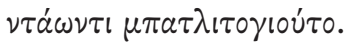

Modern Greek Paraphrase

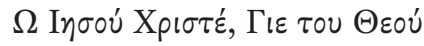

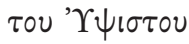

$\phi \omega s$ a $\lambda \eta \theta_{1} \nu \sigma^{\prime} \pi \circ v \pi \rho \circ{ }^{\prime} \lambda \theta \varepsilon$

$\alpha \pi^{\prime} \tau 0 \phi \omega s$

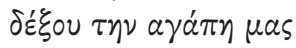

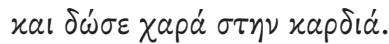

$\Omega \Delta \eta \mu 10 \cup \rho \gamma \varepsilon \dot{\varepsilon} \Sigma \varepsilon \varepsilon \xi u \mu \nu \varepsilon \dot{~}$

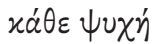

$\tau \eta \varsigma \alpha \gamma \alpha \dot{\alpha} \pi \eta \varsigma \eta \pi \eta \gamma \eta \dot{ }$

$\eta$ a $\tau \tau \varepsilon i ́ p \varepsilon \cup \tau \eta$

$\varepsilon \dot{\varepsilon} \lambda \omega \omega \varepsilon \varepsilon \dot{\varepsilon} \sigma^{\prime} \varepsilon \mu \alpha \dot{s} \varsigma$

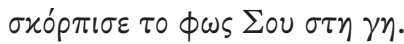

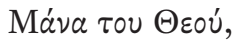

$\sigma \tau \dot{\eta} \rho l \gamma \mu \alpha$ xal $\varepsilon \lambda \pi i \delta \alpha \mu \alpha \varsigma$

$\sigma \varepsilon \pi \alpha \rho a x a \lambda o u ́ \mu \varepsilon$

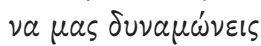

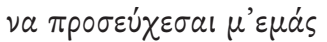

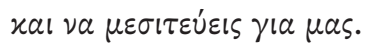

In Syriac script the left hand column represents:

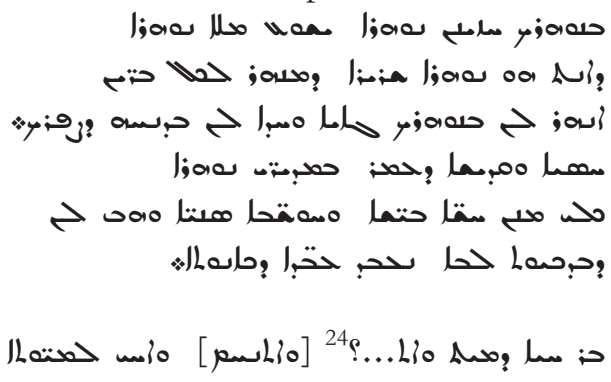

24 The Greek transcription suggests ioghio 'and was amazed', but this gives no sense in the context. 


\section{مسه حمحا حمحن: مهح:ا حمحتحا

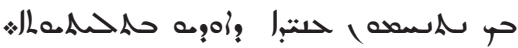

Comparison of the Syriac text with the Modern Greek translation will quickly show that the translation is extremely free, and indeed can hardly be called a translation at all for the second and third verses!

\section{Table VI}

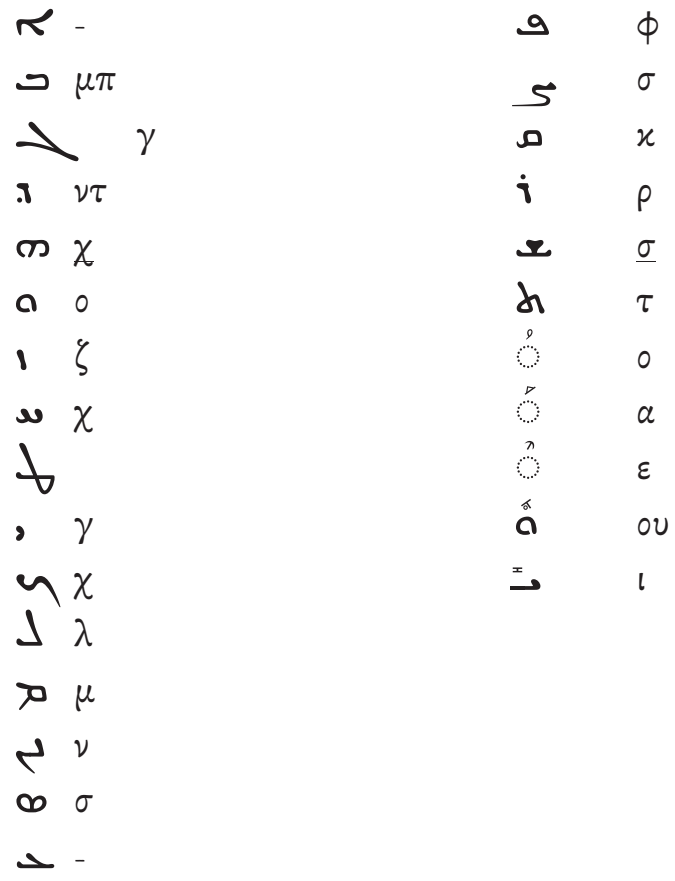

The aim of this contribution has primarily been concerned just to draw attention to these little-known documents, which are potentially of considerable interest both from socio-linguistic point of view, and from that of the history of the Greek language. In the case of the Maronite texts of Section D, the reason for the shift from Greek in Syriac script to Syriac in Greek script is clear: the 
former was for the use of only the priest, while the latter was for the benefit of the Greek-speaking laity. In the case of the examples in Sections A and B, the situation is less clear, though in each of the four examples the text will have been intended for use only by the clergy, and not by the laity; furthermore, one assumes that the clergy using these texts were very familiar with both languages, for without a good knowledge of Greek it is often not easy to read that language in Syriac script, especially as the word division is sometimes incorrect. The choice of script will thus probably have primarily been dictated by the script in which the copyists were first trained to write, and which the clergy, who would be using them, had first learn to read. By contrast with the other examples, the Missale Romanum in Syriac script in Section C was almost certainly never intended for practical use.

In the case of the Damascus fragment, the rubrics are in Syriac, as are some of the prayers, but the most important parts, and the responses of the people, are in Greek, and the Greek is much more than just fossilized short phrases. This suggests that the fragment is a witness to a period of transition from the use of Greek in the liturgy to that of Syriac. Sauget took this feature to point to a Melkite origin for the fragment, despite the fact that the inclusion of the phrase 'we break the heavenly bread' was a feature whose presence is best attested in the Syrian Orthodox tradition. Perhaps one should not rule out the possibility that there were still Greekspeaking Syrian Orthodox communities in certain localities of Syria as late as the tenth century. 25

Sinai Syr. 27, with a collection of troparia, will have had a more limited, and very probably a monastic, context, and one that would suit a multilingual milieu such St Catherine's monastery, which, especially in the thirteenth century, had a strong presence of Syriacreading monks, usually originating from different localities in Syria. This will also apply to E18N, which was almost certainly a product of that monastery.

The case of the Christian Palestinian Aramaic manuscript, Or. 4951, is more uncertain, though it too could have originated for use in the same monastery, from which the large majority of surviving

${ }^{25}$ It should also be remembered that the late tenth and first half of the eleventh century was the period of the Byzantine reconquest of north west Syria. 
manuscripts in that dialect come. But in any case the scribe will have originated from Palestine, rather than Syria.

It is to be hoped that the extensive Greek texts in Syriac script that are to be found in both Sinai Syr. 27 and British Library Or. 4951, will one day receive the attention of a specialist in the history of medieval Greek. Although most of the vowel changes to which these texts witness had already taken place before the time of the Arab conquests, and much earlier than the date of the manuscripts, the texts do, however, seem to provide some interesting sidelight on the shift in the pronunciation of upsilon from [ü] to [i], which is generally recognized as having taken place well after the other Greek vowel shifts. ${ }^{26}$ In this connection it is unfortunate that the manuscripts in question all lack any precise date, though the Damascus fragment is pretty certainly the earliest, perhaps belonging to the tenth century. The other two examples in Section A are certainly later, and Sauget's date of eleventh/twelfth century for Sinai Syr. 27 seems reasonable. ${ }^{27}$ The Christian Palestinian Aramaic manuscript of Section B is likely to belong to a similar date.

In summary, the information that is likely to be of relevance for the history of the Greek language in the medieval between approximately the tenth and the twelfth/thirteenth century is as follows:

(a) Vowels

-As would be expected by the end of the first millennium AD, all the witnesses in Sections A and B treat $\alpha \iota$ and $\varepsilon$ alike.

-The Damascus fragment employs the same symbols for $v$ and ol, implying that these still represented [ü], and differentiates them from ov.

-Sinai Syr. 27 employs the same symbol for both ou and $u$, differentiating these from ol, which itself is differentiated from $\eta, l, \varepsilon l$.

-In view of its lack of diacritical marks for the vowels, E18N is not of any help on this issue.

${ }^{26}$ See in general R. Browning, Medieval and Modern Greek (London, 1969), and especially $\mathrm{H}$. Tonnet, Histoire du grec moderne. La formation d'une langue (Paris, 1993), pp.27-8, 44-6.

${ }^{27}$ Sauget, 'Manuscrits sinaïtiques dispersés, III', p.33. 
-Both E18N and the Christian Palestinian Aramaic text represents the pronunciation of $\alpha v$ and $\varepsilon v$ as [af], [ef].

-In the Christian Palestinian Aramaic text $v$ and or are treated in the same way as $\eta$, $\iota$, and $\varepsilon$, indicating that the shift [ü] to [i] had by now taken place.

(b) Consonants

-The pronunciation of $\chi$ as [s] before front vowels is found in Sinai Syr. 27, E18 and the Christian Palestinian Aramaic witness.

-E18N witnesses to the shift [nt] to [nd].

Although the corpus of Greek liturgical texts written in Syriac and Christian Palestinian Aramaic scripts is not nearly as extensive or important as the edition of a vernacular Greek translation of the Pentateuch printed in Hebrew script in Constantinople in 1547,28 it nevertheless deserves some attention. ${ }^{29}$

${ }^{28}$ D.C. Hesseling, Les cinq livres de la Loi (Leiden/Leipzig, 1897); on it, see N. Fernández Marcos, The Septuagint in Context. Introduction to the Greek Versions of the Bible (Leiden, 2000), pp.180-2, and especially Tonnet, Histoire du grec moderne, pp.92-101.

${ }^{29}$ Closer in time and character would be the examples of rubrics in Greek language but written in Hebrew script in several Passover Haggadah fragments from the Cairo Geniza, for which see N. de Lange, Greek Jewish Texts from the Cairo Genizah (Texte und Studien zum Antiken Judentum 51; Tübingen, 1996), pp.50-53, 62-3; in the same volume de Lange publishes a vernacular Greek translation of Qohelet, also written in Greek characters (pp.,71-78). 